\title{
ZUSES
}

science for a changing world

Prepared in cooperation with the U.S. Bureau of Reclamation and the Hopi Tribe

\section{Characterization of Subsurface Geologic Structure for Potential Water Resources near the Villages of Moenkopi, Arizona, 2009-2010}

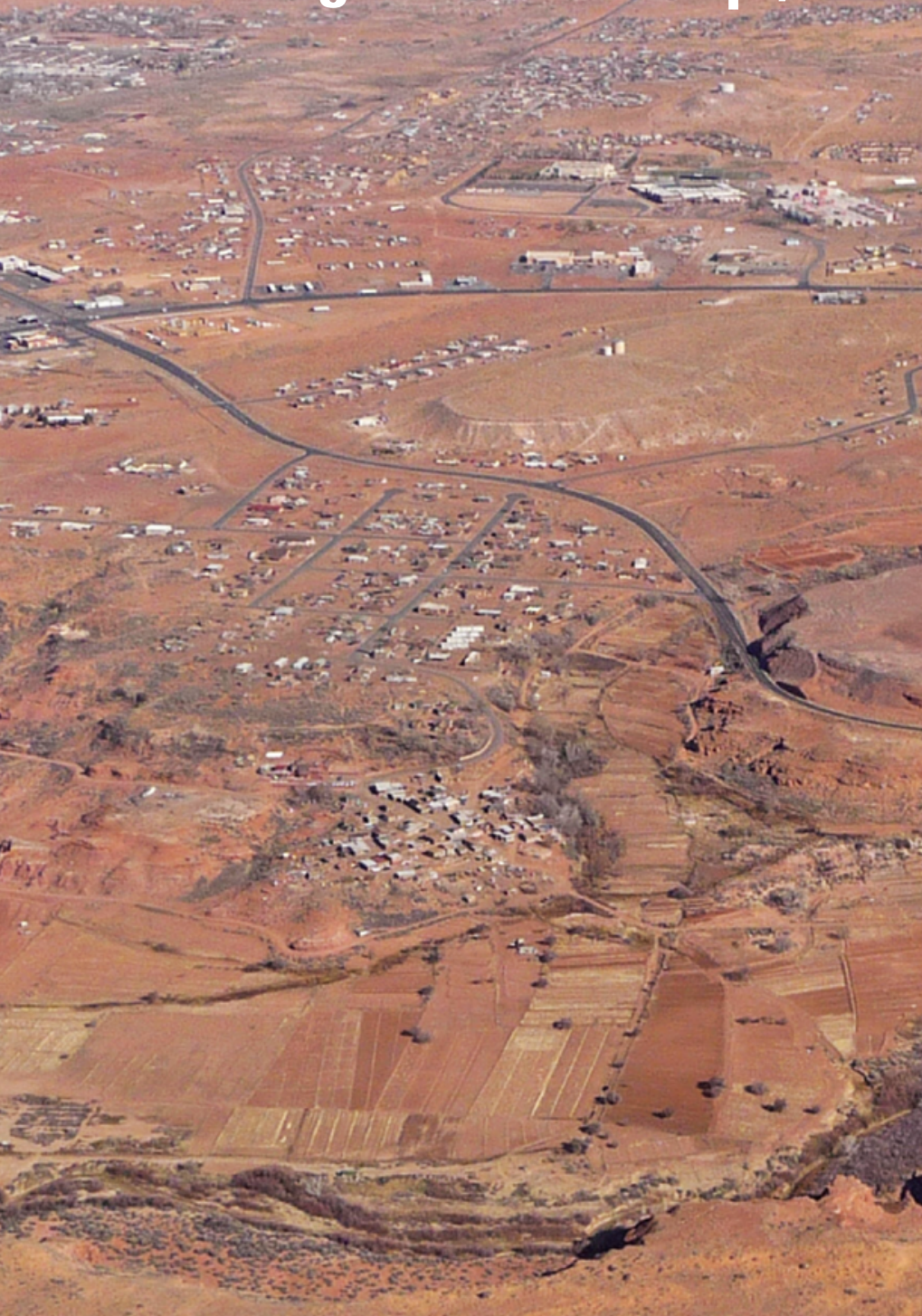

Scientific Investigations Report 2012-5180

U.S. Department of the Interior U.S. Geological Survey 


\section{Characterization of Subsurface Geologic Structure for Potential Water Resources near the Villages of Moenkopi, Arizona, 2009-2010}

By Jamie P. Macy

Prepared in cooperation with the U.S. Bureau of Reclamation and the Hopi Tribe

Scientific Investigations Report 2012-5180 


\title{
U.S. Department of the Interior \\ KEN SALAZAR, Secretary \\ U.S. Geological Survey \\ Marcia K. McNutt, Director
}

\author{
U.S. Geological Survey, Reston, Virginia: 2012
}

For more information on the USGS - the Federal source for science about the Earth, its natural and living resources, natural hazards, and the environment, visit http://www.usgs.gov or call 1-888-ASK-USGS.

For an overview of USGS information products, including maps, imagery, and publications, visit http://www.usgs.gov/pubprod

To order this and other USGS information products, visit http://store.usgs.gov

Any use of trade, product, or firm names is for descriptive purposes only and does not imply endorsement by the U.S. Government.

Although this report is in the public domain, permission must be secured from the individual copyright owners to reproduce any copyrighted materials contained within this report.

Suggested citation:

Macy, J.P., 2012, Characterization of subsurface geologic structure for potential water resources near the Villages of Moenkopi, Arizona, 2009-2010: U.S. Geological Survey Scientific Investigations Report 2012-5180, 24 p.

(Avaliable at http://pubs.usgs.gov/sir/2012/5180/.) 


\section{Contents}

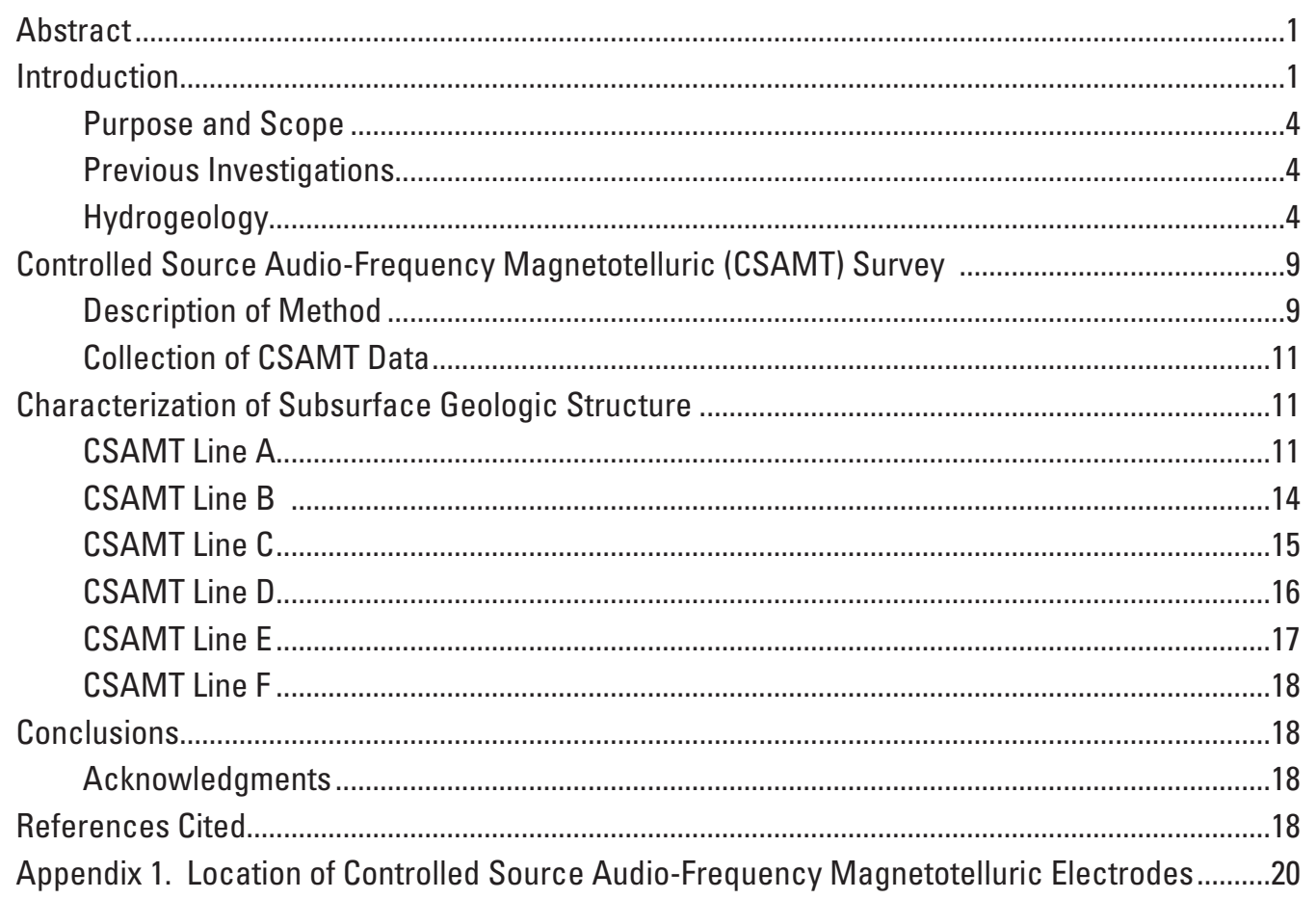

\section{Figures}

1. Map showing study area, including the Villages of Moenkopi, Arizona.................................

2. Map showing Moenkopi supply wells and Tuba City Landfill in the study area near the Villages of Moenkopi, Arizona........................................................................................ 3

3. Geologic map of the area near the Villages of Moenkopi, Arizona, 1969 ................................5

4. Geologic map of the Tuba City Landfill and adjacent Pasture Canyon near the Villages of Moenkopi, Arizona .................................................................................

5. Geologic map of Pasture Canyon and adjacent areas near the Villages of Moenkopi, Arizona .........................................................................

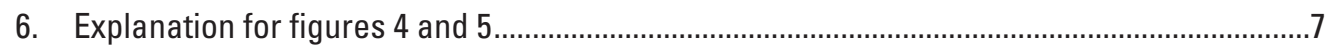

7. Stratigraphic columnar section for area near the Villages of Moenkopi, Arizona...................8

8. Map showing water-table elevations near the Villages

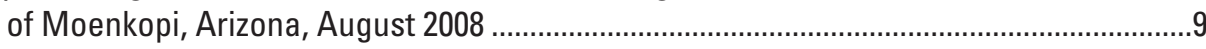

9. Diagram showing controlled source audio-frequency magnetotelluric set-up .....................10

10. Graphs showing results of geophysical survey near the Villages of Moenkopi, Arizona, December, 2009 ..................................................................................... 12

11. Graphs showing results of geophysical survey near the Villages of Moenkopi, Arizona, December, 2009..................................................................... 13

12. Graphs showing results of geophysical survey near the Villages of Moenkopi, Arizona, April, 2010.................................................................................

13. Graphs showing results of geophysical survey near the Villages of Moenkopi, Arizona, April, 2010 
14. Graphs showing results of geophysical survey near the Villages of Moenkopi, Arizona, April, 2010

15. Graphs showing results of geophysical survey near the Villages of Moenkopi, Arizona, September, 2010.

\section{Tables}

1-1. Receiver Station Location of each CSAMT electrode for Line A...........................................

1-2. Receiver Station Location of each CSAMT electrode for Line B. ........................................21

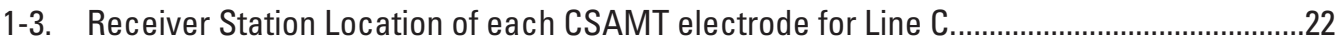

1-4. Receiver Station Location of each CSAMT electrode for Line D..........................................

1-5. Receiver Station Location of each CSAMT electrode for Line E.........................................23

1-6. Receiver Station Location of each CSAMT electrode for Line F..........................................24

\section{Conversion Factors and Datums}

SI to Inch/Pound

\begin{tabular}{|c|c|c|}
\hline Multiply & By & To obtain \\
\hline \multicolumn{3}{|c|}{ Length } \\
\hline meter (m) & 3.281 & foot $(\mathrm{ft})$ \\
\hline kilometer $(\mathrm{km})$ & 0.6214 & mile (mi) \\
\hline \multicolumn{3}{|c|}{ Flow rate } \\
\hline Liter per second (Lps) & 15.85 & Gallons per minute (gpm) \\
\hline \multicolumn{3}{|c|}{ Resistivity } \\
\hline Ohm-meters & 3.281 & Ohm-foot \\
\hline
\end{tabular}

Vertical coordinate information is referenced to North American Vertical Datum of 1988 (NAVD 88).

Horizontal coordinate information is referenced to North American Datum of 1983 (NAD 83).

Elevation, as used in this report, refers to distance above the vertical datum. 


\title{
Characterization of Subsurface Geologic Structure for Potential Water Resources near the Villages of Moenkopi, Arizona, 2009-2010
}

\author{
By Jamie P. Macy
}

\section{Abstract}

The Hopi Tribe depends on groundwater as their primary drinking-water source in the area of the Villages of Moenkopi, in northeastern Arizona. Growing concerns of the potential for uranium contamination at the Moenkopi water supply wells from the Tuba City Landfill prompted the need for an improved understanding of subsurface geology and groundwater near Moenkopi. Information in this report provides the Hopi Tribe with new hydrogeologic information that provides a better understanding of groundwater resources near the Villages of Moenkopi. The U.S. Geological Survey in cooperation with the U.S. Bureau of Reclamation and the Hopi Tribe used the controlled source audio-frequency magnetotelluric (CSAMT) geophysical technique to characterize the subsurface near Moenkopi from December 2009 to September 2010. A total of six CSAMT profiles were surveyed to identify possible fracturing and faulting in the subsurface that provides information about the occurrence and movement of groundwater. Inversion results from the six CSAMT lines indicated that north to south trending fractures are more prevalent than east to west. CSAMT Lines A and $\mathrm{C}$ showed multiple areas in the Navajo Sandstone where fractures are present. Lines B, D, E, and F did not show the same fracturing as Lines A and $\mathrm{C}$.

\section{Introduction}

Water supplies are diminishing for the Upper Village of Moenkopi and Lower Village of Moencopi (referred to in this report as the Villages or the Villages of Moenkopi) in northeastern Arizona. The Villages are on Hopi Tribal Lands south of and topographically lower than the Navajo community of Tuba City, Arizona. (fig. 1). The Villages have a combined population of about 900-1,000 residents, and Tuba City has a population of about 8,600 (U.S. Census Bureau, 2011). Three Tribal supply wells near the Villages (fig. 2) are developed into the Navajo (N) aquifer to depths of 43, 44, and 67 meters. Navajo Tribal Utility Authority (NTUA) wells that supply Tuba City are developed much deeper in the $\mathrm{N}$ aquifer and have much higher yields. The static water level and well yield in Moenkopi supply well 3 (MSW3; fig. 2) has declined substantially, by about 20 percent. Moenkopi supply well 2 (MSW2; fig. 2) has gone dry at times. The static water level in Moenkopi supply well 1 (MSW1; fig. 2), at total depth of 43 meters, has declined about 15 meters but still maintains a yield of about 2.5 liters per second. The estimated adequate water supply for the Villages is about 4.7 liters per second. Additional water resources are needed by the Hopi Tribe to address the water needs of the Villages.

Several undeveloped springs are in the Moenkopi area and at least one developed spring in the vicinity of the Villages of Moenkopi (fig. 2). The flow of the developed spring, Susunova Spring (also called Moenkopi School Spring by the U.S. Geological Survey [USGS]), has declined substantially (Macy and Brown, 2011). Flow at Susunova Spring has decreased from about 1.0 liters per second in 1987 to 0.5 liters per second in 2010. Residents of the Villages use Susunova Spring as an additional water resource.

In addition to the diminishing water supply, groundwater quality in the area of the Villages of Moenkopi may be at risk due to a possible contaminant plume of uranium and other trace elements from the Tuba City Landfill (TCL) located east of the Moenkopi supply wells (fig. 2). Maximum dissolved uranium concentrations in the plume are about 200 parts per billion, with average concentrations of about $30-40$ parts per billion. The current U.S. Environmental Protection Agency (USEPA) maximum contaminant level (MCL) for public drinking-water supply is 30 parts per billion (U. S. Environmental Protection Agency, 2009). The TCL started as an unregulated waste disposal site in the 1940s. The Bureau of Indian Affairs began environmental monitoring of the TCL in 1995, and by 1997 the TCL was administratively closed due to the discovery of radionuclides in shallow groundwater at levels that exceeded the USEPA MCLs.

Growing concern about the water resources near the Villages and the possible contamination of the drinking-water source from a uranium plume near the Villages led to the involvement of the USGS to characterize subsurface geologic structure in the $\mathrm{N}$ aquifer near the Villages. In 2009 the U.S. Bureau of Reclamation, in cooperation with the Hopi Tribe Water Resources Program, requested the expertise of the 



Figure 1. Map showing study area, including the Villages of Moenkopi, Arizona. 




Figure 2. Map showing Moenkopi supply wells and Tuba City Landfill in the study area near the Villages of Moenkopi, Arizona. 
USGS to better understand the occurrence and movement of groundwater near the Villages. Because the primary waterbearing zone in the area of the Villages of Moenkopi is the $\mathrm{N}$ aquifer, geophysical tools were used to characterize structures such as fractures within the $\mathrm{N}$ aquifer.

This report presents the findings from six geophysical profiles that were completed from 2009 to 2010 to define subsurface geologic structure near the Villages of Moenkopi. The geophysical technique, controlled source audio-frequency magnetotelluric (CSAMT) survey, was used as the primary tool to define subsurface structure and to provide additional information about the occurrence and movement of groundwater in the $\mathrm{N}$ aquifer underlying the study area. Modeled results of the CSAMT surveys are presented and discussed in relation to the local geology and groundwater-flow system.

\section{Purpose and Scope}

The purpose of this report is to describe the findings from six geophysical surveys completed during 2009-10 near the Villages of Moenkopi. Results from these geophysical surveys will provide the Hopi Tribe with additional information about the occurrence and movement of groundwater near the Villages.

\section{Previous Investigations}

Concerns regarding potential local contamination of drinking water from the Tuba City Landfill have led to investigations of the area near the Villages of Moenkopi. Johnson and others (2009) conducted resistivity surveys in the area of the TCL as part of an interagency agreement with the Bureau of Indian Affairs. The purpose of the study was to map the extent of the leachate plume near the TCL and better define the local groundwater system in and around the landfill. Results from the study did not indicate the presence of a conductive leachate plume, but did indicate moderately conductive zones indicative of the presence of groundwater with relatively low total dissolved solids concentrations. Northeast of the TCL, the resistivity surveys identified several shallow, conductive zones, interpreted as groundwater flow paths. Southwest of the TCL, the resistivity data indicate that groundwater flow paths converge into a single branch that flows southwesterly toward Pasture Canyon Wash.

Johnson and others (2008) presented geochemical data from the analyses of rock, sediment, and groundwater collected beneath and adjacent to the TCL. Johnson and others (2008) also performed solid-phase leaching experiments in the laboratory on solid material from the Tuba City Open Dump. In addition, a companion report (Otton and others, 2008) released geologic information and limited hydrologic and geochemical information about the TCL. Results from the study show that a section of gently northeast-dipping sedimentary rocks of Jurassic age underlies the TCL and vicinity. Surficial sediments are composed of eolian sand and fluvially reworked eolian sand that overlies the Navajo Sandstone of Jurassic age located underneath the TCL. Results from geochemical analyses (Johnson and others, 2008) show that deeper groundwater in the Navajo Sandstone consists of dilute calcium-bicarbonate water that is low in all trace elements, including uranium. However, shallow groundwater is variably affected by near-surface processes that add varying amounts of sodium, chloride, sulfate, and trace elements, including uranium. According to Johnson and others (2008) local human influences such as the TCL could possibly affect the shallow groundwater system.

Johnson and others (2009) presents the results and interpretation of USGS data collected in and around the TCL. This report is a series of presentation slides given on March 3 and 4, 2009, in Phoenix, Ariz., for a Bureau of Indian Affairs technical meeting. The purpose of the report and presentation were to answer questions about the source of uranium and other constituents of interest in groundwater in and around the TCL. The results from the report indicate that uranium, associated major and trace elements, and other constituents of interest are stored in the vadose zone through a possible cycle of wind-blown deposition, dissolution, and concentration by evapotranspiration; thus sediments high in uranium from the Chinle Formation are blown into the area of the TCL. The sediments are deposited and come in contact with precipitation. Uranium is dissolved out of the sediments and into the water. Continual evapotranspiration concentrates the dissolved uranium. An important finding of the report was that elevated uranium and other constituents occur in shallow groundwater throughout the area, except where $\mathrm{N}$ aquifer water discharges at the surface as springs.

Johnson and Wirt (2009) is a follow-up report to Johnson and others (2008). The follow-up report presents the findings from geochemical data analysis of five TCL wells and of various regional rocks, sediments, groundwater, springs, and surface water. The findings focus on a comparison of the geochemistry in rocks and water in the Tuba City region. Findings from the study indicate that uranium concentrations in water near the TCL are above the concentrations typically found in the Navajo Sandstone and Kayenta Formation. In addition, this study indicates that the sources of the uranium appear to be closely related to material derived from the Chinle Formation. The Chinle Formation is exposed to the southwest of the Tuba City area and this material is potentially being transported by the dominant southwest to northeast wind direction.

\section{Hydrogeology}

Bedrock near the Villages consists of the lower part of the Navajo Sandstone, the informally named Kayenta FormationNavajo Sandstone transition zone (KNTZ), and the Kayenta Formation, all of Jurassic age (figs. 3-7; Cooley and others, 1969; Billingsley and others, 2007). Bedrock units in the area gently dip about 2 degrees to the northeast (Cooley and others, 1969). The Navajo Sandstone is the principal aquifer in the study area and is the primary stratigraphic unit of the $\mathrm{N}$ aquifer (fig. 7). The Navajo Sandstone consists of red and white, cliff-forming, crossbedded eolian sandstone and can 


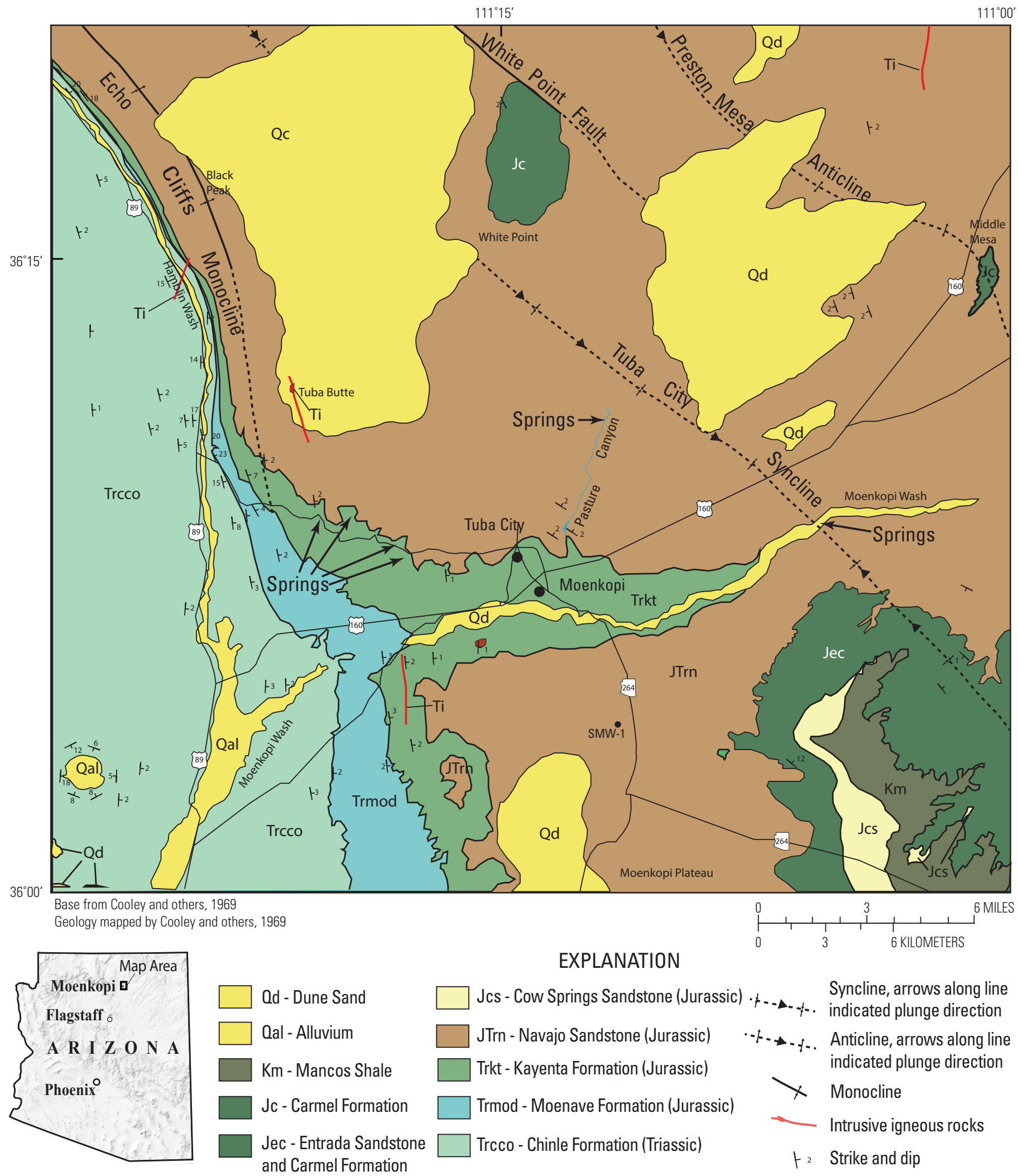

Figure 3. Geologic map of the area near the Villages of Moenkopi, Arizona, 1969 (modified from Cooley and others, 1969, pl. 1). 




Figure 4. Geologic map of the Tuba City Landfill and adjacent Pasture Canyon near the Villages of Moenkopi, Arizona (modified from Otton and others, 2008). See figure 6 for explanation.

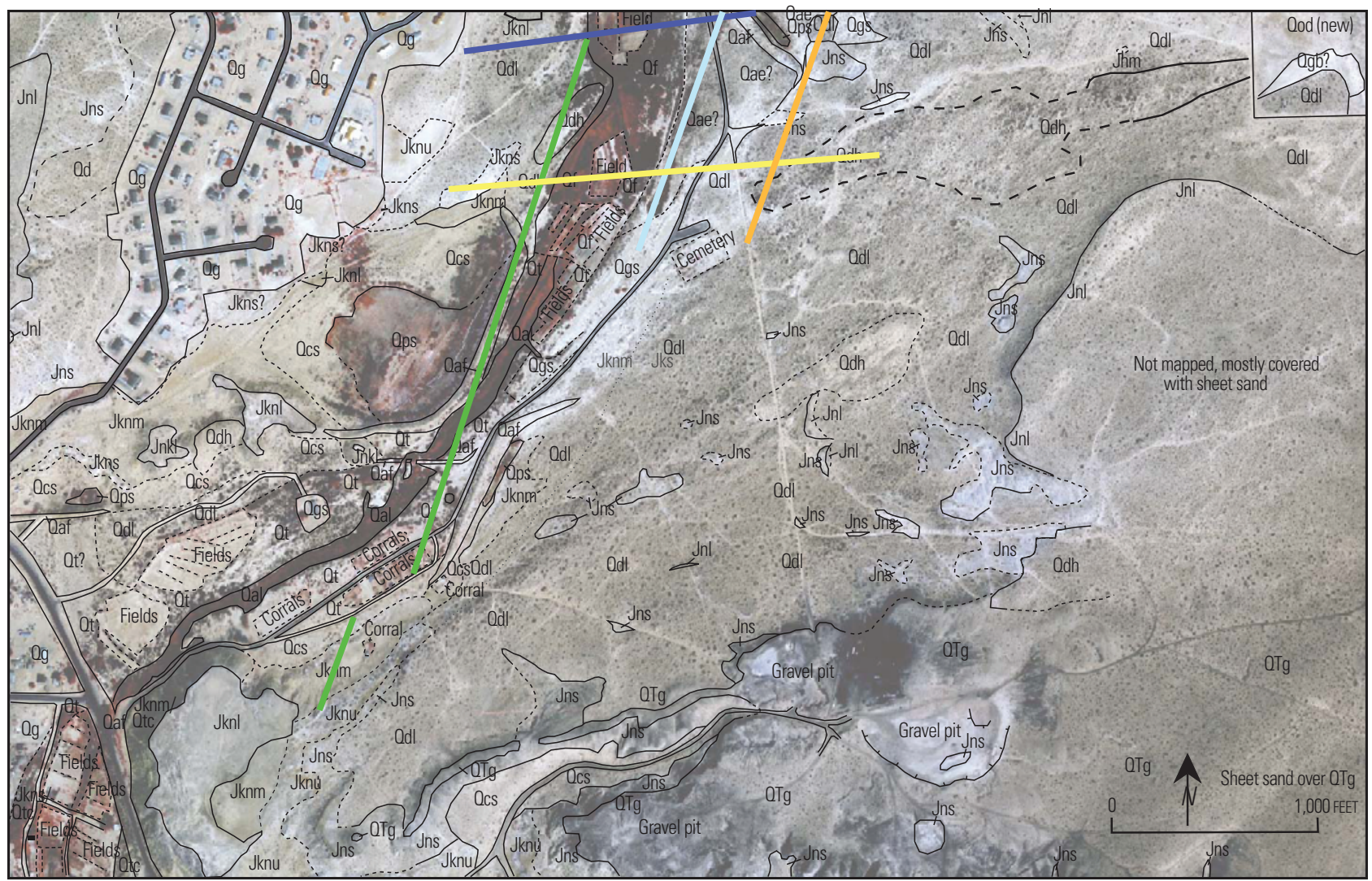

Figure 5. Geologic map of Pasture Canyon and adjacent areas near the Villages of Moenkopi, Arizona (modified from Otton and others, 2008). See figure 6 for explanation. 
EXPLANATION

Oaf Artificial fill employed in road, reservoir, and flood-control berms. Along U.S. Highway 160 and State Highway 264, this unit also includes the asphalt pavement.

Og Graded and otherwise disturbed areas that are underlain by both bedrock and sand.

Ogb Graded and otherwise disturbed areas underlain primarily by bedrock. May include some areas underlain by eolian sand.

Ogs Graded and otherwise disturbed areas underlain primarily by sand. May include some areas where weathered Navajo Sandstone is exposed. Includes one borrow pit.

Ood Open dump areas. Disturbed areas underlain by trash interlayered with sand used to cover the trash. Includes the old road berm that extends from the old open dump west to U.S. Highway 160. A washout in the old road berm near the Navajo-Hopi fence shows fill interlayered with domestic trash. In the new open dump area, graded areas underlain by sand with no subsurface trash are mapped with this unit. An area of bulldozed disturbed ground adjacent to the old road berm is included.

Ops Ponded sediment. Sediment (clay, silt, and sand) deposited in low areas dammed by berms.

Oal Young, fine-grained sediment in the bottom of the gully that dissects the floodplain of Pasture Canyon.

Of Floodplain deposits. Sediment deposited by flood waters along Pasture Canyon; this generally flat topography has been converted to agriculture in several areas (not mapped separately).

Ot Terrace deposits indistinguishable from Qf and mapped in Pasture Canyon below the point where a gully dissects the floodplain surface (Qf).

Ocs Colluvium and sheetwash deposits on gentle slopes.

Otc Talus and colluvium deposits formed on steep slopes.

Qae Water reworked eolian or a mix of eolian and alluvial channel and floodplain deposits. This unit is mapped along the washes that pass north then west of the old open dump. It merges with the floodplain deposits along Pasture Canyon. The contact between Of and Qae is difficult to distinguish because the area is disturbed by roads. The map unit is characterized by low topography with low vegetated hummocks. The surface of this map unit is actively being eroded by modern stream flow, and narrow incised channels as much as 1 meter deep have cut down into it southwest of the old road berm and north of U.S. Highway 160.

Od Dunes and eolian sheet sand. Odl- Dune and sheet sand areas marked by low hummocks (generally less than 1 meter high). Odh- Hummocky dune deposits with relief to as much as 3 meters. In both areas hummocks are formed by vegetative trapping of wind-blown sediment and deflation of the intervening areas. Includes two areas of young dunes along Pasture Canyon.

QTg Variably cemented gravels that cap the mesa in the southeast corner of fig. 4.

Jn Navajo Sandstone. Jns- Sandstone, generally massively cross-bedded. Variably colored in outcrop and the subsurface. Occurs in cliff faces, on slopes below a mesa caprock. Locally forms low, ribbed outcrop areas.

Jnl Limestone beds within the lower Navajo Sandstone. Forms capping ledges on small mesas within the map area. Two horizons are present. One horizon caps the small mesa west and southwest of the old open dump and is probably equiv alent to the limestone that caps the mesa just east of Pasture Canyon and north of U.S. Highway 160. The other horizon is a stratigraphically higher limestone that caps the mesa south of the new open dump. Exposures of the limestone in the disturbed area east of Pasture Canyon and north of U.S. Highway 160 include overlying red-brown mudstone, siltstone, and thin limestone.

Jkn Kayenta-Navajo transition zone sedimentary rocks. Sandstone, siltstone and mudstone undivided (Jknu), sandy siltstone, siltstone, mudstone (Jknm), sandstone (Jkns), limestone (Jknl). Mapped mostly on the west side of Pasture Canyon.

CSAMT Receiver Transects

Figure 6. Explanation for figures 4 and 5 (modified from Otton and others, 2008). 
range in thickness from 48 to $76 \mathrm{~m}$ in the area of the Villages of Moenkopi (Billingsley and others, 2007). Near Tuba City, springs emerge at the contact between the Navajo Sandstone and the Kayenta Formation and are evident along Pasture Canyon, Moenkopi Wash, and the Echo Cliffs monocline (fig. 3). The Navajo Sandstone and Kayenta Formation interfinger near the Villages of Moenkopi, and the contact between these two stratigraphic units is not distinct (fig. 7). Billingsley and others (2007) informally named the rocks between the Navajo Sandstone and Kayenta Formation the KNTZ. In the study area, the KNTZ consists of alternating mudstone, siltstone, and sandstone, which likely has a local influence on shallow groundwater paths (Johnson and Wirt, 2009). The KNTZ can range in thickness from about 37 to $73 \mathrm{~m}$ (Billingsley and others, 2007). The Kayenta Formation underlies the Navajo Sandstone and consists of purple mudstones and siltstones interbedded with cobbles (figs. 4 and 7: Morgan, 2002). The Kayenta Formation can range in thickness from about 98 to $122 \mathrm{~m}$ near the Villages of Moenkopi (Billingsley and others, 2007). Although the Navajo Sandstone is the principal waterbearing unit of the $\mathrm{N}$ aquifer, the upper facies of the Kayenta Formation can also be water bearing (Truini and others, 2004).

Surficial deposits near the Villages of Moenkopi consist of Quaternary eolian sand sheet and sand dune deposits, fluvial, and ponded sediments (figs. 4-6). Dune features are common and cover much of the surface near the Villages of Moenkopi (figs. 4-6). Eolian sands consist of very fine grained to fine-grained sand typically colored pale reddish-orange to moderate reddish-orange (Otton and others, 2008).

Structure in the area of the Villages of Moenkopi plays a role in the movement of groundwater. The Tuba City syncline is located about 8 kilometers to the northeast of the Villages, trends northwest to southeast, and plunges to the southeast (fig. 3). Moenkopi Wash intersects the Tuba City syncline east of the Villages. Water preferentially moves along the syncline from northwest to southeast, and springs are evident where the syncline intersects with Moenkopi Wash. Other major geologic structures in the area also trend northwest to southeast or north-northwest to south-southeast, including the Echo Cliffs monocline. Numerous fractures have been mapped in the area of the Villages and Tuba City; fractures follow north to south, north-northwest to south-southeast, and northnortheast to south-southwest trends (George Billingsley, U.S. Geological Survey, personal commun., 2012). On the north cliff face of Moenkopi Wash to the southeast of the Villages of Moenkopi, there are numerous fractures exposed with north to south, north-northwest to south-southeast, and north-northeast to south-southwest trends (fig. 2). Fractures are often found in the areas within the Navajo Sandstone where the greatest potential for groundwater resources exist. Fractures in the Navajo Sandstone can produce large amounts of water and may provide a good source of drinking water (Truini, 1999).

The direction of groundwater movement near the TCL is west to southwest toward Pasture Canyon Wash (fig. 8). Little is known about the role Pasture Canyon Wash plays in groundwater movement, but a reservoir upstream of the study area on Pasture Canyon Wash inhibits surface water from travelling south.

Wells near the Villages of Moenkopi that were considered for this study are drilled into the Navajo Sandstone and Kayenta Formation and consist of the three Moenkopi supply wells and a single test well south of Moenkopi Wash, tribal well SMW-1 (fig. 1). Three Moenkopi supply wells are completed to depths of 43, 44, and 67 meters. Moenkopi supply well 1 (MSW1; fig. 2), land-surface elevation of 1,477 meters and total depth of 44 meters, contains sandstone, interpreted to be the Navajo Sandstone, from the land surface to a depth of about 41.5 meters. Below 41.5 meters, the sandstone layers interbed with shale and clay and represent the interfingering relation in the KNTZ. A hard, red sandy clay at 52 meters depth is interpreted as the Kayenta Formation. Moenkopi supply well 2 (MSW2; fig. 2), land-surface elevation of 1,477
Figure 7. Stratigraphic columnar section for area near the Villages of Moenkopi, Arizona.

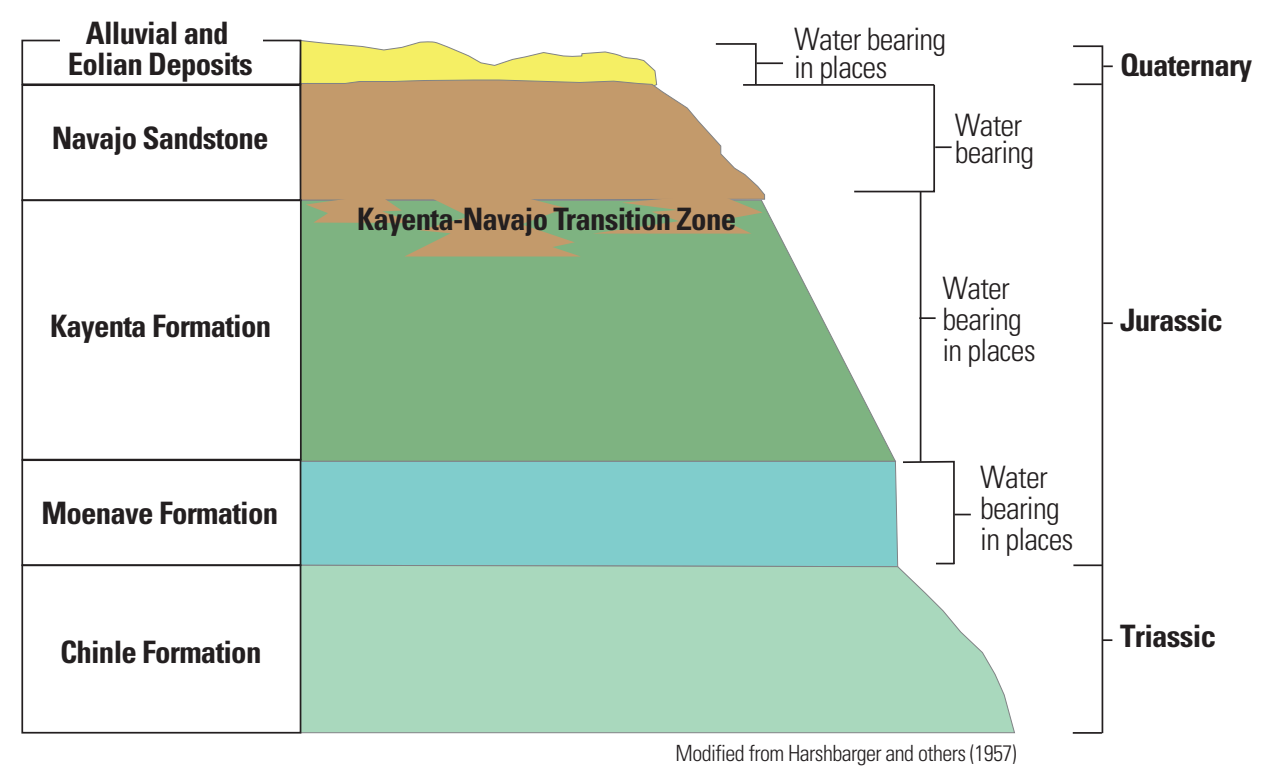




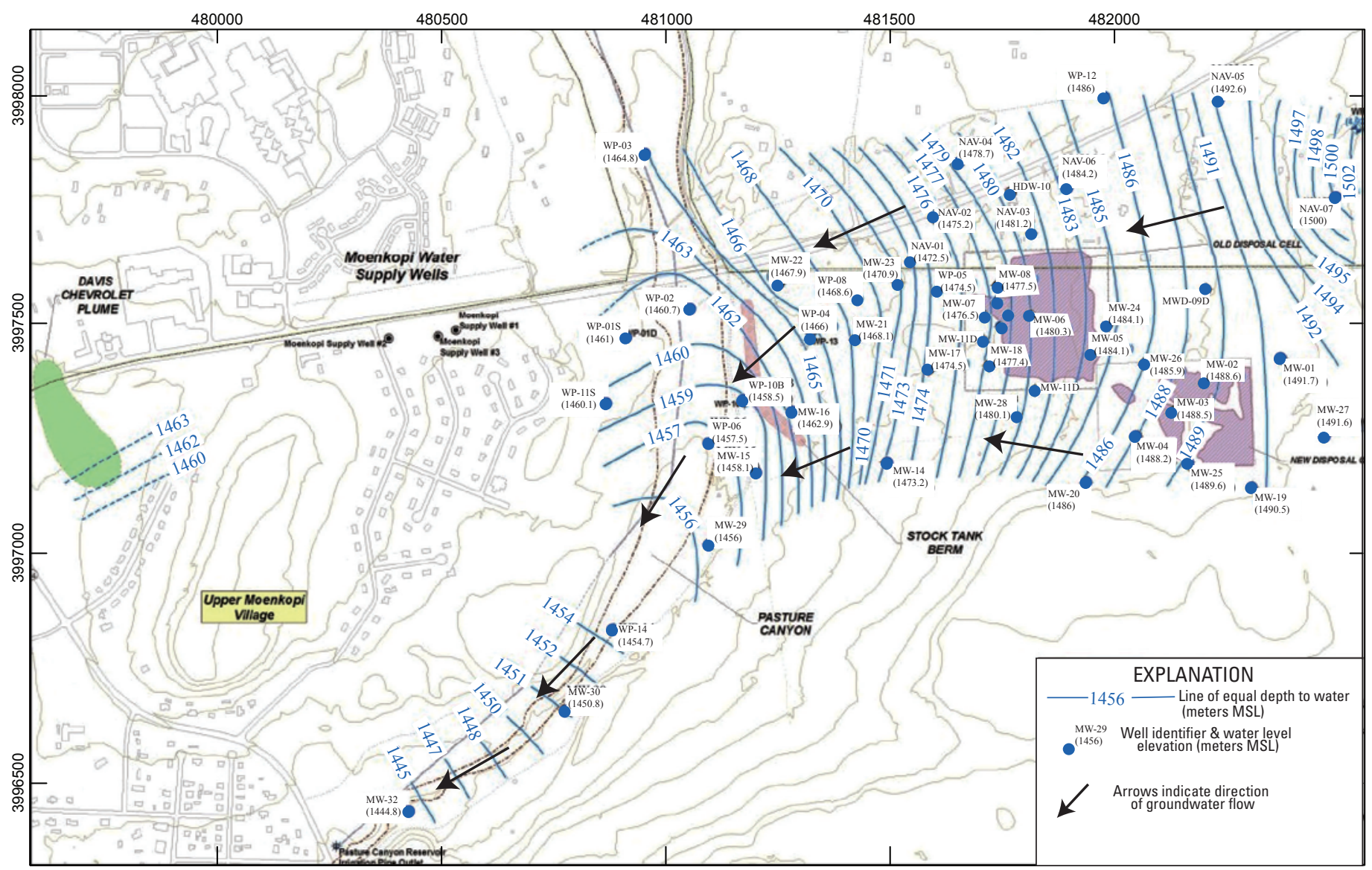

Figure 8. Map showing water-table elevations near the Villages of Moenkopi, Arizona, August 2008 (modified from Johnson and others, 2008; Johnson and others, 2009)

meters and total depth of 43 meters, is about 150 meters west of MSW1 and has similar characteristics. Sandstone is the dominant lithology in MSW2 to a depth of about 38 meters, where red shale is encountered to the bottom of the well. The well is completed in the red shale, which represents either a finger of the Kayenta Formation within the KNTZ or the beginning of the Kayenta Formation. Moenkopi supply well 3 (MSW3; fig. 2), land-surface elevation of 1,477 meters and total depth of 67 meters, is located between MSW1 and MSW2 and has similar characteristics as the other Moenkopi supply wells. South of Moenkopi Well 1 (SMW-1; fig. 1.) is located south of Moenkopi Wash and was drilled to a depth of 232 meters and completed in the Kayenta Formation.

Navajo Sandstone is present in SMW-1 from the land surface to a depth of 85 meters or 1,480 meters elevation. Below the Navajo Sandstone is the Kayenta Formation from a depth of 85 to 232 meters or 1,480 to 1,330 meters elevation. The Kayenta Formation here is described by the driller's log as a reddish-brown, moderately well sorted silt with very fine grained sand, subangular to subrounded quartz, slightly friable to hard, well-cemented, and calcareous. The static water level in SMW-1 is 32.2 meters below land surface. The driller's log from this well does not differentiate between the KNTZ and Kayenta Formation.

\section{Controlled Source Audio-Frequency Magnetotelluric (CSAMT) Survey}

CSAMT is an electromagnetic sounding technique that has proven useful for hydrogeological and groundwater studies (Zonge, 1992). CSAMT is a geophysical method that can provide subsurface information about geologic units, geologic structure, and water content to depths of 3,000 meters below land surface. This low-impact, non-intrusive technique has been used extensively by the minerals, geothermal, hydrocarbon, and groundwater exploration industries since 1978, when CSAMT equipment systems first became commercially available (Zonge, 1992)

\section{Description of Method}

CSAMT calculates the electrical resistivity of the subsurface along a receiver profile by measuring electric and magnetic fields introduced into the earth by transmitting a controlled current at several frequencies a specified distance away (fig. 9). Because the electrical resistivity varies with rock types and water content, this method may provide an 
indication of subsurface structure (strata, faults, and fractures) and presence of groundwater (Simpson and Bahr, 2005). Grounded dipoles at the receiver site detect the electric field parallel to the transmitter, and a magnetic coil antenna senses the perpendicular magnetic field (fig. 9). The ratio of the orthogonal- and horizontal-electric field magnitudes to magnetic field magnitudes yields the apparent resistivity. CSAMT uses a remote, grounded electric dipole transmitter as an artificial signal source. The transmitter source provides a stable signal, resulting in higher precision and faster measurements than what can be obtained from natural source audio-frequency magnetotelluric (Zonge, 1992). Typically the source for a CSAMT survey should be separated from the survey line by about five times the depth of investigation because a plane wave is advantageous (fig. 9).

CSAMT measurements typically are made at frequency ranges from 1 to 8,000 hertz in binary incremental steps. For example, the frequencies of $2,4,8,16,32,64,128,256,512$, $1,024,2,048,4,096$, and 8,192 hertz would be measured. CSAMT measurements consist of orthogonal and parallel components of the electric $(E)$ and magnetic $(H)$ fields at a separation of 5 to 15 kilometers from the source (Sharma, 1997). CSAMT measurements can be taken in a number of different arrays depending on the type of information warranted. This study used a "reconnaissance" type of CSAMT array, which consists of one electric $(E x)$ and one magnetic (Hy) component for each measurement (Zonge, 1992), as opposed to a more involved survey, which collects vector and tensor measurements by measuring two electric-field components ( $E x$ and $E y$ ) and three magnetic-field components $(H x, H y$, and $H z)$. Multiple electric fields are measured concurrently during reconnaissance CSAMT surveys. This study also used a six-channel receiver, which has the capability of simultaneously measuring five electric fields for every one magnetic field. Because the magnetic field does not change much over the same distance that substantial electricfield changes occur, fewer magnetic-field measurements are required. The magnetic-field measurement is used to normalize the electric fields and calculate the apparent resistivity and phase difference (Zonge, 1992). Grounded dipoles at the receiver site measure the electric field parallel to the transmitter $(E x)$, and a magnetic coil antenna measures the perpendicular magnetic field $(H y)$. The ratio of the $E x$ and $H y$ magnitudes yield the apparent resistivity (equation 1; Zonge, 1992; Simpson and Bahr, 2005):

$$
\rho_{a}=1 / 5 f[E x / H y]^{2},
$$

where $\rho_{a}$ is the apparent resistivity, $f$ is the frequency, $E x$ is the electrical-field strength, and $H y$ is the magnetic-field strength.

The penetration of CSAMT into the subsurface and the depth of investigation is determined by the skin depth (equation 2):

$$
S=503 \sqrt{ }\left(\rho_{a} / f\right)
$$

where $\rho_{a}$ is the measured apparent ground resistivity in ohmmeters, and $f$ is the signal frequency (Zonge, 1992; Simpson and Bahr, 2005). The skin depth is the depth at which the amplitude of a plane wave signal has dropped to 37 percent of its value at the surface (Zonge, 1992). The skin depth is pertinent in CSAMT surveys because CSAMT data are most commonly interpreted by using simplified magnetotelluric (MT) equations, which are based on the assumption that the electric and magnetic fields behave as plane waves. Unlike MT soundings, where the source of telluric current (distant lightning strikes or atmospheric interaction with solar winds) is considered infinitely distant and nonpolarized, the CSAMT source is finite in distance and distinctly polarized (Sharma, 1997). The separation, $r$, between the transmitter and receiver for CSAMT surveys must be greater than three skin depths for the current driven into the ground to behave like plane waves (termed "far field"). When $r$ is less than three skin depths at the frequency being measured, the electric and magnetic fields no longer behave as plane waves and become curved ("near field") such that the equation for Cagniard resistivity (equation 1) no longer applies. CSAMT measurements from this study were examined for near- and far-field effects before modeling by plotting the apparent resistivity versus the frequency for a given set of soundings. All data from this study used for modeling are measured in the far field. The minimum distance between the source and receiver was 5 kilometers, yielding an $r$ of greater than three skin depths (Zonge, 1992).

When the $r$ between the receiver and transmitter is greater than three skin depths, the equation for depth of investigation is (Zonge, 1992):

$$
D=356 \sqrt{ }\left(\rho_{a} / f\right) .
$$

Figure 9. Diagram showing controlled source audio-frequency magnetotelluric set-up (from Zonge, 1992).




The depth $(D)$ of investigation of a CSAMT survey can range from 20 to 3,000 meters depending on the resistivity of the ground and the frequency of the signal. Lower frequency signals have a greater depth of investigation than higher frequency signals.

\section{Collection of CSAMT Data}

CSAMT data were collected near the Villages of Moenkopi (fig. 2) during December 16 to 18, 2009 (Lines A and B); April 20 to 23, 2010 (Lines C,D, and E); and September 28 to 30, 2010 (Line F). A Zonge GGT-30 geophysical transmitter powered by and connected to a 25-kilowatt trailer-mounted generator, and a Zonge XMT-32 transmitter controller was used to transmit the electrical source through a 1-kilometer-long dipole. A Zonge GDP-32II multichannel geophysical receiver was connected to six porous pot electrodes arranged in 20-meter dipoles (except Line A which used a 10-meter dipole) and a Zonge ANT3 highgain mu-metal core magnetic antenna to measure the earth's response to the transmitted signal. CSAMT field measurement set-ups consisted of one magnetic-field measurement with five accompanying electric-field measurements. Six CSAMT lines were surveyed as a part of this project, Lines A, B, C, D, E, and F (figs. 1 and 2). Three different transmitter locations were used, but each line only had one transmitter location (fig. 1). No single CSAMT line had two transmitter locations and, therefore, a single $E x$ and $H y$ field were measured at each dipole for each line. Once survey lines were complete, data were processed and analyzed using Zonge Engineering's DATPRO suite of software (Zonge Engineering, Tucson, Arizona). Raw CSAMT data were first averaged using Zonge's CSAVG program. Averaged data were reviewed for nearfield and far-field effects by plotting the apparent resistivity versus the frequency (equation 2) for a given set of soundings. The lowest far-field frequency was determined, and data below that frequency, which violated the plane wave approximation because of an insufficient separation, $r$, were not used in the analysis. Typically for the surveys near the Villages of Moenkopi, 8 hertz was the lowest far-field frequency used for analysis. After determining the lowest far-field frequency, averaged data were entered into Zonge's SCS2D software for inversions. Data were inverted by SCS2D and examined for errors. Adjustments were made to the models in areas where the geology was known; Line F near well SMW-1 is the only place where a CSAMT survey went through well control. Final inversion models represent the best fit of collected data to model curves and are presented below.

\section{Characterization of Subsurface Geologic Structure}

The results from inversion models of the six CSAMT surveys indicate that north-south structures are more dominant in the area of the Villages of Moenkopi than east-west structures. Modeled CSAMT data were visually displayed as a cross section for each surveyed line (figs. 10-15) and are presented and described below.
Inversion results from all lines indicate three electric layers that correlate with stratigraphic layers at depth (figs. $10 B-15 B)$. The first layer is thin and moderately conductive, 20 to $50 \mathrm{ohm}$-meters (green to yellow). This layer is interpreted as eolian sand deposits that are common in the area of the Villages of Moenkopi. The second layer is more resistive, 20 to greater than $126 \mathrm{ohm}$-meters (greater than $200 \mathrm{ohm}$-meters for Line A) and represents the Navajo Sandstone (yellow to orange to red); the unit crops out at land surface in some locations. The third layer is more conductive, about 1 to $10 \mathrm{ohm}$-meters (purple to blue) and probably represents a tongue of the Kayenta Formation within the KNTZ. In the area of the Villages of Moenkopi, the Kayenta Formation in the KNTZ can be a redbrown sandy siltstone and siltstones.

Along most lines, vertically oriented conductive areas occur within the Navajo Sandstone that probably represent large, saturated fractures. Fractures filled with water have the effect of lowering the resistivity and therefore are visible as conductive areas within a more resistive layer. These conductive areas are important because they represent possible waterfilled fractures that are potentially good water resources or conduits for contaminant transport. In the area of the Villages of Moenkopi, the dominant geologic faults and fractures are in a northwest to southeast or north to south direction.

\section{CSAMT Line A}

Line A is an east-west trending transect located parallel and just south of U.S. Highway 160 (fig. 2). Line A is 750 meters in total length, and the receiver dipole spacing is 10 meters. Inversion results from Line A indicate three stratigraphic layers with depth (fig. 10B). The first layer is thin, less than 10 meters, and moderately conductive, 20 to 50 ohm-meters (green to yellow; fig. 10). This layer is interpreted as Quaternary eolian sand deposits that are common in the area of the Villages of Moenkopi. The second layer is more resistive, 20 to greater than $200 \mathrm{ohm}$-meters, which is interpreted as the Navajo Sandstone (yellow to orange to red). The second layer is between elevations of 1,470 and 1,420 meters. In some areas, such as between electrodes 185 and 375, the resistive material is at the surface. In areas east of Pasture Canyon near electrodes 295 and 325, Navajo Sandstone is observed at the surface. The third layer of the inverse model from Line A is more conductive, about 1 to $10 \mathrm{ohm}$-meters (purple to blue) and probably represents a tongue of the Kayenta Formation within the KNTZ. This layer is below about 1,420 meters elevation. In the area of the Villages, the contact between the Navajo Sandstone and the KNTZ is a red-brown sandy siltstone and siltstones.

Two important features along Line $\mathrm{A}$ are the conductive areas between electrodes 35 to 65 and 385 to 415 at elevations of 1,470 to 1,420 meters. Resistivity values range from about 1 to $5 \mathrm{ohm}$-meters (purple to blue) for these features within the Navajo Sandstone layer, which typically has resistivity values of 20 to greater than $200 \mathrm{ohm}$-meters. The conductive areas within the Navajo Sandstone probably represent large 



Figure 10. Graphs showing results of geophysical survey near the Villages of Moenkopi, Arizona, December, 2009, for Line A: $A$, West to east cross section of controlled source audio-frequency magnetotelluric, smooth-model inversion results. $B$, Interpretations of inversion results. 


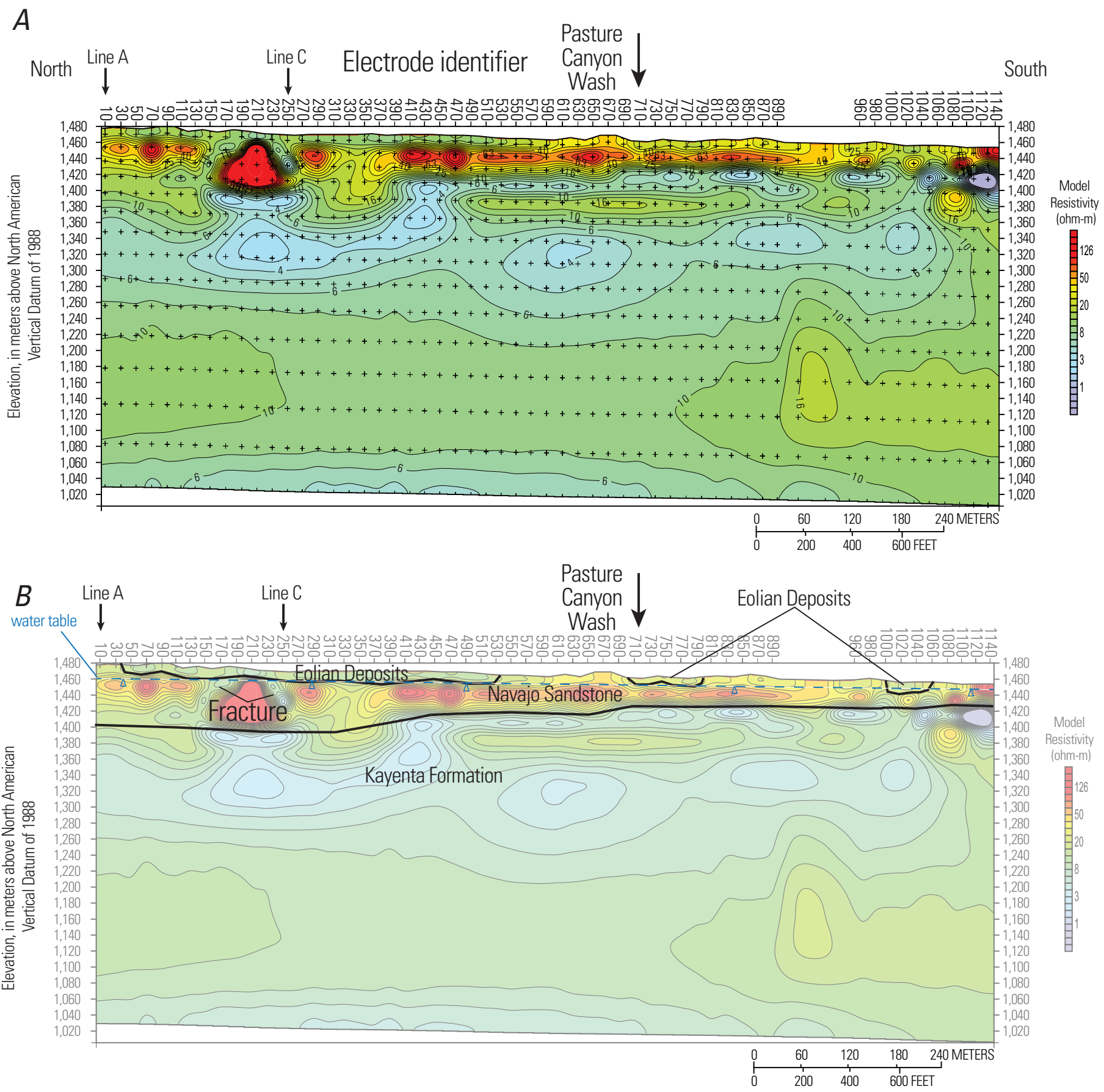

Figure 11. Graphs showing results of geophysical survey near the Villages of Moenkopi, Arizona, December, 2009, for Line B: $A$, North to south cross section of controlled source audio-frequency magnetotelluric, smooth-model inversion results. $B$, Interpretations of inversion results. 
saturated fractures. Fractures that are filled with water have the effect of lowering the resistivity and therefore are distinguished as conductive areas within a more resistive layer. These conductive areas are important because they represent possible water-filled fractures that are potentially water bearing. In the area of the Villages Moenkopi, fractures and faults are oriented north-south.

\section{CSAMT Line B}

Line B is a north-south transect on the west side of Pasture Canyon Wash (fig. 2). The line originates in the area of Line A to the north and extends southward past the intersection with Pasture Canyon Wash. There is an offset to the northwest at the southern end of Line B between electrodes 900 and 960 to go around a small structure and horse corral. Inversion model results from Line B indicate three stratigraphic layers (fig. 11B). The first layer is thin, found from the surface to a depth of less than 5 meters, and moderately conductive, 20 to 50 ohm-meters (green to yellow). This layer is interpreted as eolian sand deposits that are common in the area of the Moenkopi Villages. The second layer is a more resistive area, 20 to greater than $126 \mathrm{ohm}$-meters, which is interpreted as the Navajo Sandstone (yellow to orange to red). The second layer is between elevations of 1,470 and 1,400 meters. In some areas, such as between electrodes 530 and 690, the resistive material is at the surface. The third layer of the inverse model from Line $\mathrm{B}$ is more conductive, about 1 to $10 \mathrm{ohm}$-meters (purple to blue), which probably represents a tongue of the Kayenta Formation within the $\mathrm{KNTZ}$. This layer is below about 1,400 meters elevation.

A fracture was also crossed along Line B (fig. 11B), between electrodes 150 and 250, where conductive areas within the Navajo Sandstone layer were measured.
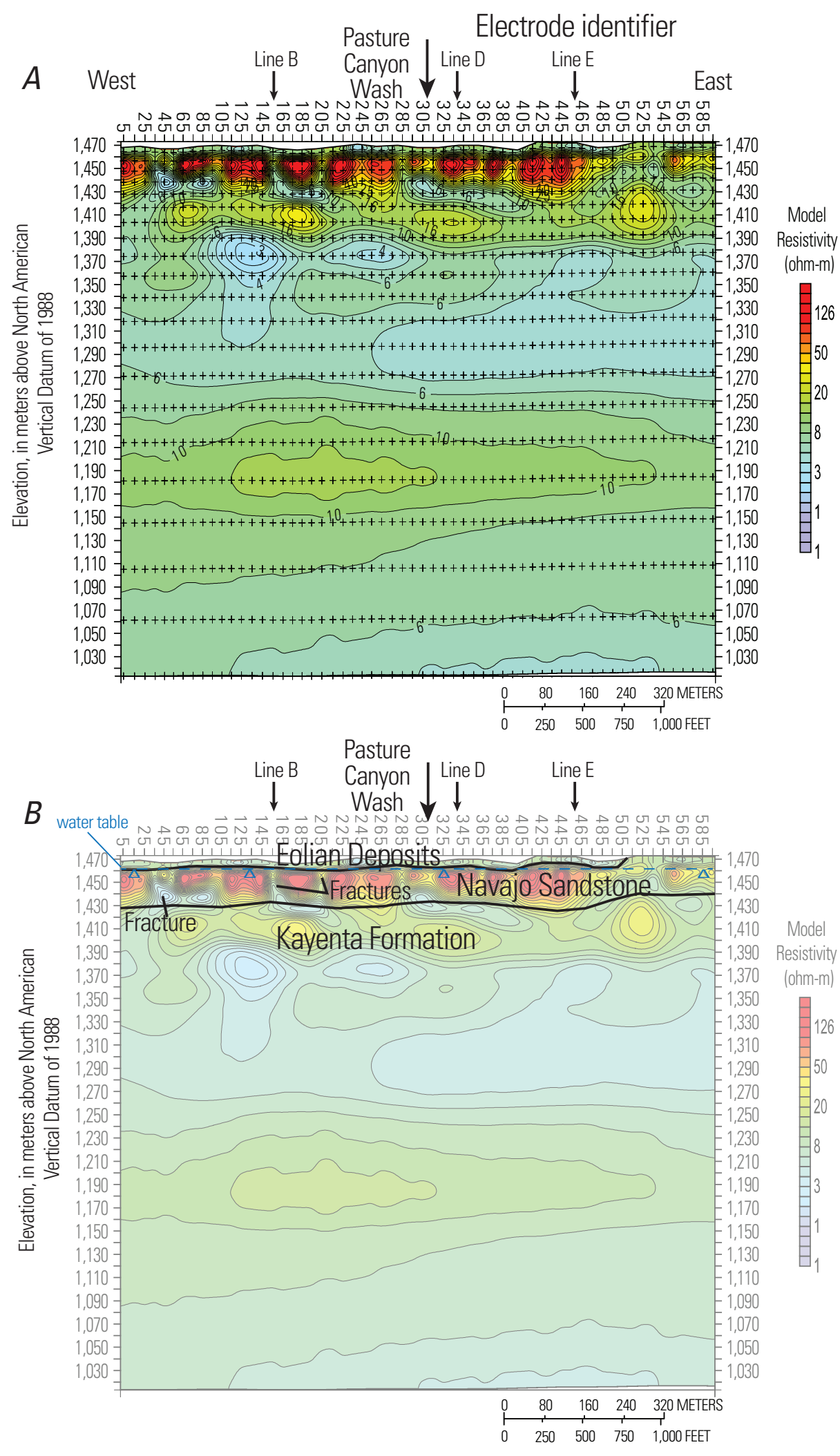

Figure 12. Graphs showing results of geophysical survey near the Villages of Moenkopi, Arizona, April, 2010, for Line C: $A$, West to east cross section of controlled source audio-frequency magnetotelluric, smooth-model inversion results. $B$, Interpretations of inversion results. 
Most of the Navajo Sandstone layer along Line B does not show the conductive fractures except in the northernmost part of the line. Line B crosses Line $\mathrm{C}$ near electrode 250 , and the same fracture from Line $\mathrm{B}$ is evident in Line $C$ (near electrode 155; fig. 11B). Dominant structures in the area of the Villages of Moenkopi, such as the Tuba City syncline and the Echo Cliffs monocline, are northwest to southeast or north to south, and Line B could possibly be crossing a northsouth fracture at an obtuse angle. So although a fracture is present on line $\mathrm{B}$, it may not be indicative of east-west trending fractures.

\section{CSAMT Line C}

Line $\mathrm{C}$ is an east-west transect parallel to and located about 200 meters south of Line A (fig. 2). Inversion model results from Line $C$ indicate three stratigraphic layers (fig. 12B). The first layer is thin and moderately conductive, 20 to $50 \mathrm{ohm}$-meters (green to yellow), and present at the surface at an elevation of about 1,470 meters. This layer is interpreted as eolian sand deposits that are common in the area of Moenkopi. The second layer is more resistive, 20 to greater than $126 \mathrm{ohm}$-meters, which is interpreted as the Navajo Sandstone (yellow to orange to red). The second layer is between elevations of 1,460 and 1,430 meters. In some areas, such as between electrodes 515 and 595, the resistive material is exposed at the surface. The third layer of the inverse model from Line $\mathrm{C}$ is more conductive, about 1 to $10 \mathrm{ohm}$-meters (purple to blue), which probably represents a tongue of the Kayenta Formation within the KNTZ. This layer is below about 1,430 meters elevation (fig. 12).

Fractures are evident along line C. Between electrodes 35 and 55 and electrodes 155 and 205, conductive material is present within the more resistive Navajo Sandstone layer (fig. 12B). These conductive areas probably represent saturated fractures, and based on the local geology, they are oriented in a north to south manner.

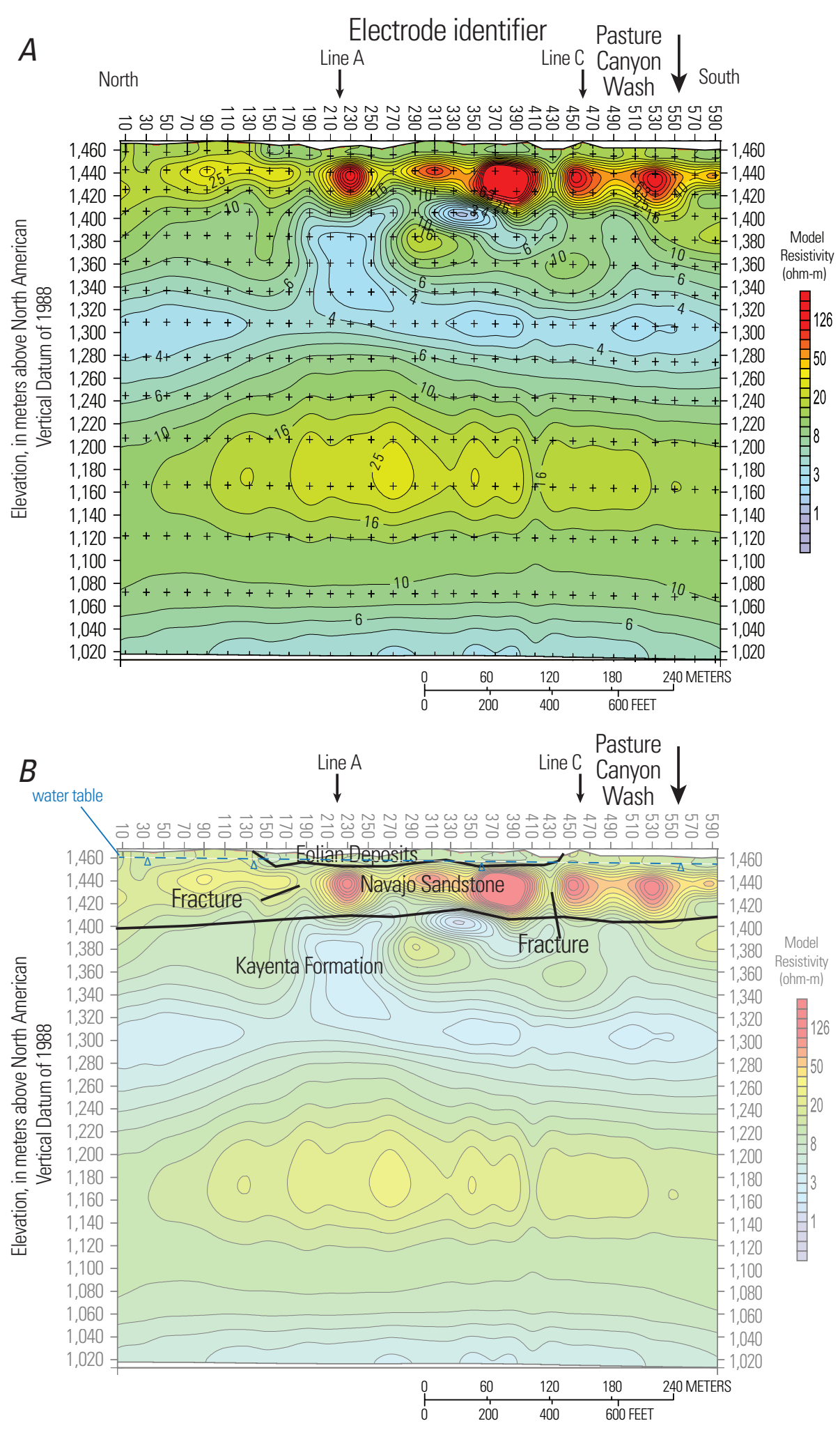

Figure 13. Graphs showing results of geophysical survey near the Villages of Moenkopi, Arizona, April, 2010, for Line D: A, North to south cross section of controlled source audio-frequency magnetotelluric, smooth-model inversion results. $B$, Interpretations of inversion results. 


\section{CSAMT Line D}

Line D is a north to south transect parallel to Line B, but located mostly on the east side of Pasture Canyon Wash (fig. 2). Inversion model results for Line D indicate three stratigraphic layers (fig. 13B). The first layer is thin and moderately conductive, 20 to $50 \mathrm{ohm}$-meters (green to yellow), between electrodes 130 and 450. This layer is interpreted as eolian sand deposits that are common in the area of Moenkopi. The second layer is more resistive, 20 to greater than $126 \mathrm{ohm}$-meters, which is interpreted as the Navajo Sandstone (yellow to orange to red). The second layer is between elevations of 1,460 and 1,400 meters. In some areas, such as between electrodes 10 and 130 and electrodes 450 and 590, the resistive material is present at the surface. The third layer of the inverse model from Line $\mathrm{D}$ is more conductive, about 1 to $10 \mathrm{ohm}$-meters (purple to blue), which probably represents a tongue of the Kayenta Formation within the KNTZ. This layer is below about 1,400 meters elevation. Below the KNTZ is the Kayenta Formation.

Near electrodes 190 and 430, resistivity values for some areas are as low as 10 to $20 \mathrm{ohm}$-meters. Although those areas could potentially be fractures, they do not look the same as other fracture areas in the Navajo Sandstone (not as conductive as fractures on Line A [1 to 5 ohm-meters; fig. 10B] or on Line C [1 to 10 ohm-meters; fig. $12 B]$ ). Whether or not those areas are fractures cannot be definitively determined, but based on other evidence in the area, they do not appear to be saturated fractures.

$A$


Resistivity (ohm-m)

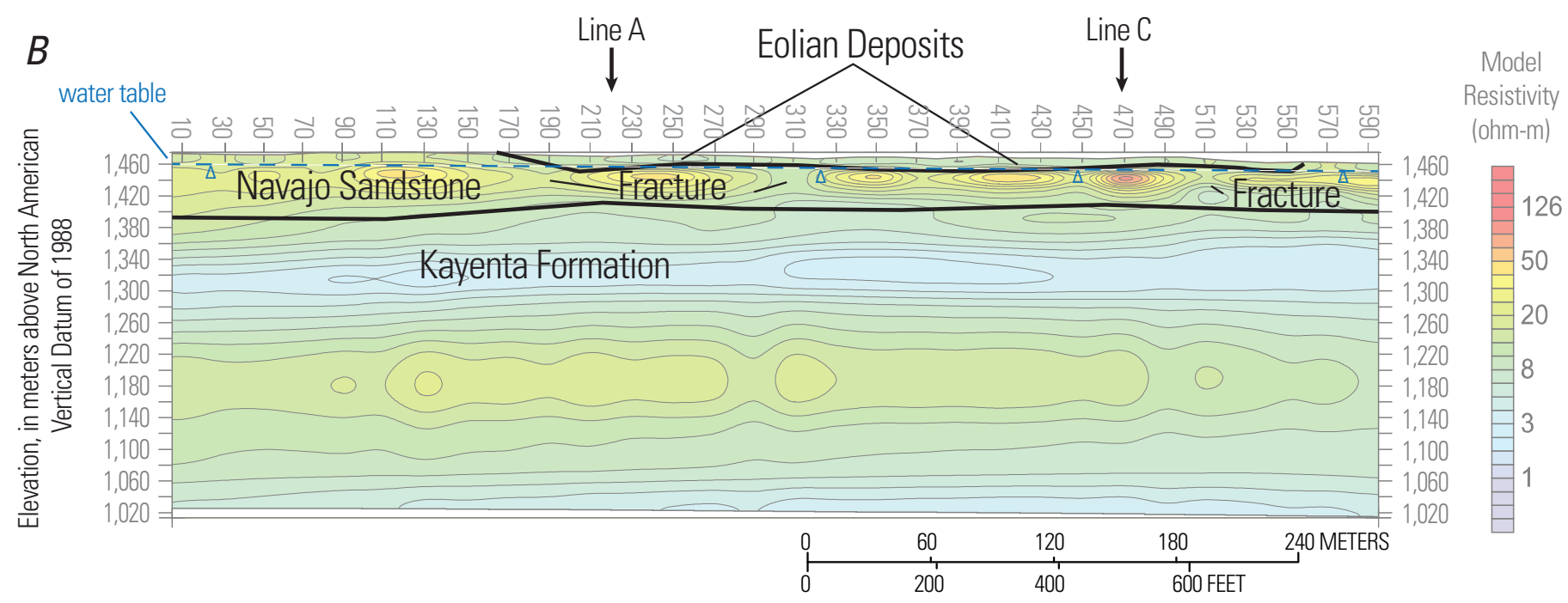

Figure 14. Graphs showing results of geophysical survey near the Villages of Moenkopi, Arizona, April, 2010, for Line E: $A$, North to south cross section of controlled source audio-frequency magnetotelluric, smooth-model inversion results. $B$, Interpretations of inversion results. 


\section{CSAMT Line E}

Line $\mathrm{E}$ is a north to south transect parallel to Lines B and $\mathrm{D}$ and located east of Pasture Canyon Wash (fig. 2). Inversion results from Line $\mathrm{E}$ indicate three stratigraphic layers (fig. 14B). The first layer is thin and moderately conductive, 20 to $50 \mathrm{ohm}$-meters (green to yellow) between electrodes 170 and 550. This layer is interpreted as eolian sand deposits that are common in the area of Moenkopi. The second layer is more resistive, 20 to greater than $126 \mathrm{ohm}$-meters, which is interpreted as the Navajo Sandstone (yellow to orange to red). The second layer is between elevations of 1,460 and 1,400 meters. In some areas, such as between electrodes 10 and 150 and electrodes 550 and 590, the resistive material is present at the surface. The third layer of the inverse model from Line $\mathrm{E}$ is more conductive, about 1 to $10 \mathrm{ohm}$-meters (purple to blue),


Figure 15. Graphs showing results of geophysical survey near the Villages of Moenkopi, Arizona, September, 2010, for Line F: $A$, West to east cross section of controlled source audio-frequency magnetotelluric, smooth-model inversion results. $B$, Interpretations of inversion results. 
which probably represents a tongue of the Kayenta Formation within the KNTZ. This layer is below about 1,400 meters elevation. Below the KNTZ is the Kayenta Formation.

One potential fracture area along Line $\mathrm{E}$ is near electrode 310 (fig. 14B). The resistivity values are between 8 and $20 \mathrm{ohm}$-meters from the land surface to an elevation of about $1,400 \mathrm{~m}$. The fracture appears as a vertical conductive feature between a semi-continuous high resistivity unit. Although other fractures in the Navajo Sandstone layer are typically closer to 1 to $10 \mathrm{ohm}$-meters, this area is potentially a fracture.

\section{CSAMT Line F}

Line $\mathrm{F}$ is an east to west transect located about 4 kilometers south of Moenkopi Wash (fig. 1). Line F was surveyed for potential water resources south of Moenkopi Wash in the area where there is an existing $\mathrm{N}$ aquifer well, SMW-1. Inversion model results from Line $\mathrm{F}$ indicate three stratigraphic layers (fig. $15 B)$. The first layer is thin and moderately conductive, 20 to $50 \mathrm{ohm}$-meters (green to yellow), between electrodes 370 and 1,190. This layer represents eolian sand deposits that are common in the area near the Villages of Moenkopi. The second layer is more resistive, 20 to greater than 126 ohm-meters, which is interpreted as the Navajo Sandstone (yellow to orange to red). The second layer is between elevations of 1,550 and 1,480 meters. In some areas, such as between electrodes 10 and 370 , the resistive material is present at the surface. The third layer is more conductive, about 1 to $10 \mathrm{ohm}$-meters (purple to blue), which probably represents a tongue of the Kayenta Formation within the KNTZ. This layer is below about 1,480 meters elevation. Below the KNTZ is the Kayenta Formation. An N aquifer test well, SMW-1 (fig. 1), was drilled in the area of Line F near electrode 1,030, and the driller's log describing Navajo Sandston and Kayenta Formation resembles the geophysical survey (fig. 15B).

\section{Conclusions}

Data from this study indicate that fractures are present in the Navajo Sandstone, primarily in a north to south orientation. Fractures identified along Line $\mathrm{A}$ and Line $\mathrm{C}$ could hold potential water resources. Large fractures were not identified along Line F. North to south survey Lines B, D, and E do not show large fracturing, but they do show some fractures. While the lack of large fractures in an east to west orientation suggests minimal potential for developing additional water resources, it does however suggest that the movement of contaminated water to the Moenkopi supply wells would be inhibited. The movement of groundwater near Moenkopi can be northeast to southwest or east to west and the presence of east to west fractures in the Navajo Sandstone could work to more easily move contaminated material through the subsurface towards the Moenkopi Supply Wells. Inversion results from geophysical surveys indicate that east to west fractures are present, but they are not as large as north to south fractures.

\section{Acknowledgments}

The author would like to thank the Hopi Tribe for their support of the project, access to Tribal lands for research, and insight into water resources near the Villages of Moenkopi. The author would also like to extend his appreciation to the Upper Village of Moenkopi and the Lower Village of Moencopi for their cooperation during the project. Appreciation is also extended to the Hopi Water Resources Department, and to Lionel Puhuyesva, Director of the Hopi Water Resources Department. The field staff from the U.S. Geological Survey Arizona Water Science Center is owed a debt of gratitude for their hard work in often perilous field conditions; specifically the author would like to thank Geoff DeBenedetto, Chris Brown, Corey Sannes, Curt Crouch, and Kurt Schonauer.

\section{References Cited}

Billingsley, G.H., Priest, S.S., and Felger, T.L., 2007, Geologic map of the Cameron 30' x 60' quadrangle, Coconino County, northern Arizona: U.S. Geological Survey Scientific Investigations Map 2977, scale 1:100,000, $33 \mathrm{p}$.

Cooley, M.E., Harshbarger, J.W., Akers, J.P., and Hardt, W.F., 1969, Regional hydrogeology of the Navajo and Hopi Indian reservations, Arizona, New Mexico, and Utah: U.S. Geological Survey Professional Paper 521-A, 61 p.

Harshbarger, J.W., Repenning, C.A., and Irwin, J.H., 1957, Stratigraphy of the Uppermost Triassic and the Jurassic Rocks of the Navajo Country: U.S. Geological Survey Professional Paper 291, 71 p.

Johnson, R.H., and Wirt. Laurie, 2009, Geochemical analyses of rock, sediment, and water from the region in and around the Tuba City Landfill, Tuba City, Arizona: U.S. Geological Survey Open-File Report 2009-1020, 44 p.

Johnson, R.H., Otton. J.K., Horton, R.J., Gallegos, T.J., Choate, L.M., and Sullivan, J.E., 2008, Geochemical data from analyses of rock, sediment, water, and solid-phase leaching at the Tuba City Open Dump, Tuba City, Arizona: U.S. Geological Survey Open-File Report 2008-1374, 10 p.

Johnson, R. H., Otton, J.K., and Horton, R.J., 2009, Results and interpretations of U.S. Geological Survey data collected in and around the Tuba City Open Dump, Arizona: U.S. Geological Survey Open-File Report 2009-1154, 125 p.

Macy, J.P., and Brown, C.R., 2011, Groundwater, surfacewater, and water-chemistry data, Black Mesa area, northeastern Arizona - 2009-10: U.S. Geological Survey Open File Report 2011-1198, 42 p. 
Morgan, R., 2002, Rapid site characterization report-The Hopi Tribe Water Resources Program: Prepared under the U.S. Environmental Protection Agency Resource and Conservation and Recovery Act Section 8001 Grant Project, $110 \mathrm{p}$.

Otton, J.K., Johnson, R.H., and Horton, R.J., 2008, Geologic maps and cross sections of the Tuba City open dump site and vicinity, with implication for the occurrence and flow of groundwater: U.S. Geological Survey Open-File Report 2008-1380, $78 \mathrm{p}$.

Sharma, P.V., 1997, Environmental and engineering geophysics: Cambridge, Cambridge University Press, XXX p.

Simpson, Fiona, and Bahr, Karsten, 2005, Practical magnetotellurics: Cambridge, Cambridge University Press, $254 \mathrm{p}$.
Truini, Margot, 1999, Geohydrology of Pipe Spring National Monument Area, Northern Arizona: U.S. Geological Survey Water-Resources Investigations Report 98-4263, $25 \mathrm{p}$.

Truini, Margot, Fleming J.B., and Pierce, H.A., 2004, Preliminary Investigation of structural controls of groundwater movement in Pipe Spring National Monument, Arizona: U.S. Geological Survey Scientific Investigations Report 2004-5082, 16 p.

Zonge, K.L., 1992, Broad band electromagnetic systems, in Van Blaricom, Richard, ed., Practical geophysics II for the exploration geologist: Northwest Mining Association, p. 439-523.

Zonge Engineering, Software, 2006, CSINV Documentation: Tucson, Arizona, Zonge Engineering Inc., 29 p. 


\section{Appendix 1. Location of Controlled Source Audio-Frequency Magnetotelluric Electrodes}

Table 1-1. Receiver Station Location of each CSAMT electrode for Line A.

[Coordinate system: Universal Transverse Mercator Zone 11, North American Datum of 1983; elevation is in meters above th North American Vertical Datum of 1988]

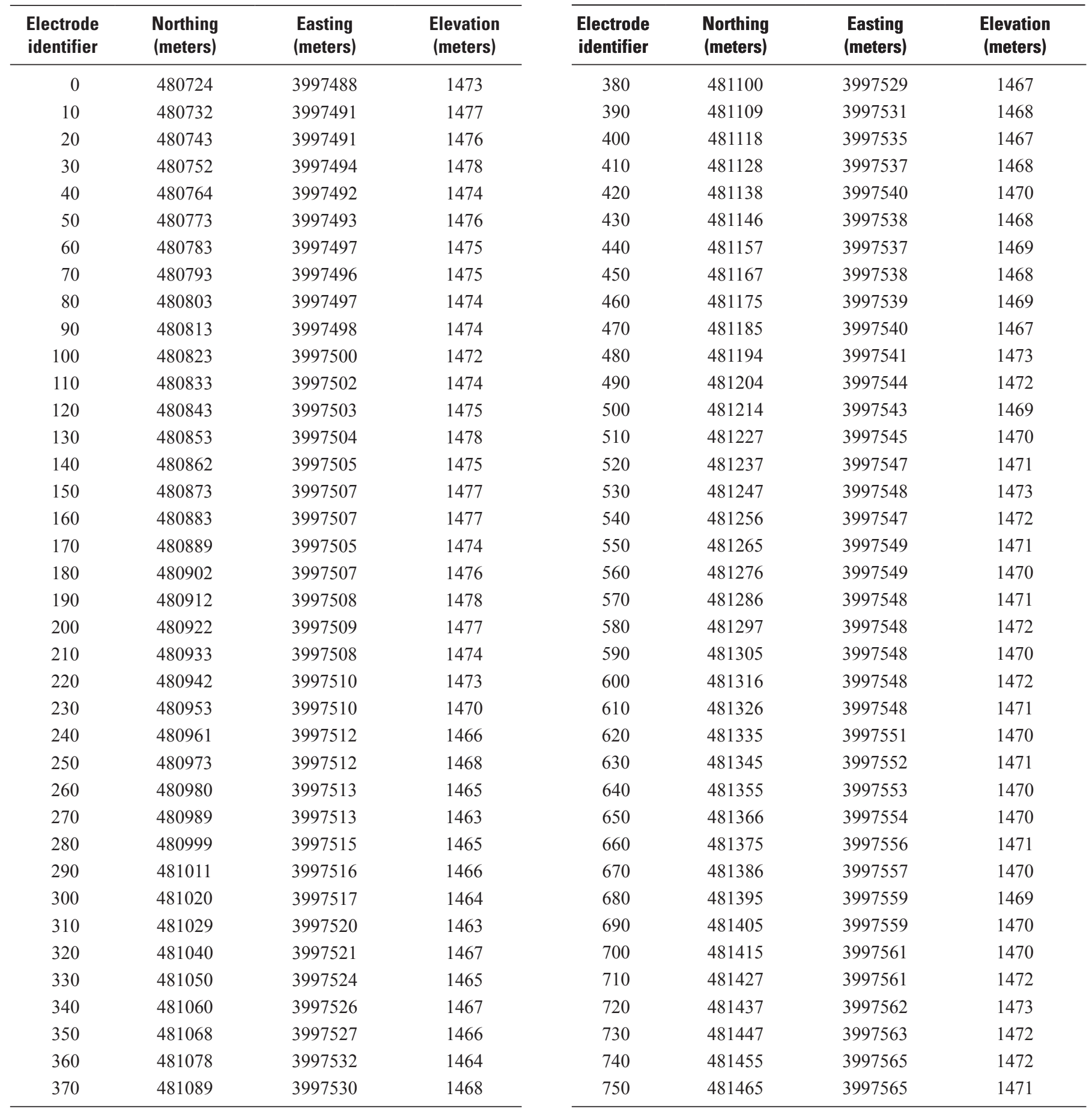


Table 1-2. Receiver Station Location of each CSAMT electrode for Line B.

[Coordinate system: Universal Transverse Mercator Zone 11, North American Datum of 1983; elevation is in meters above th North American Vertical Datum of 1988]




Table 1-3. Receiver Station Location of each CSAMT electrode for Line C.

[Coordinate system: Universal Transverse Mercator Zone 11, North American Datum of 1983; elevation is in meters above th North American Vertical Datum of 1988]

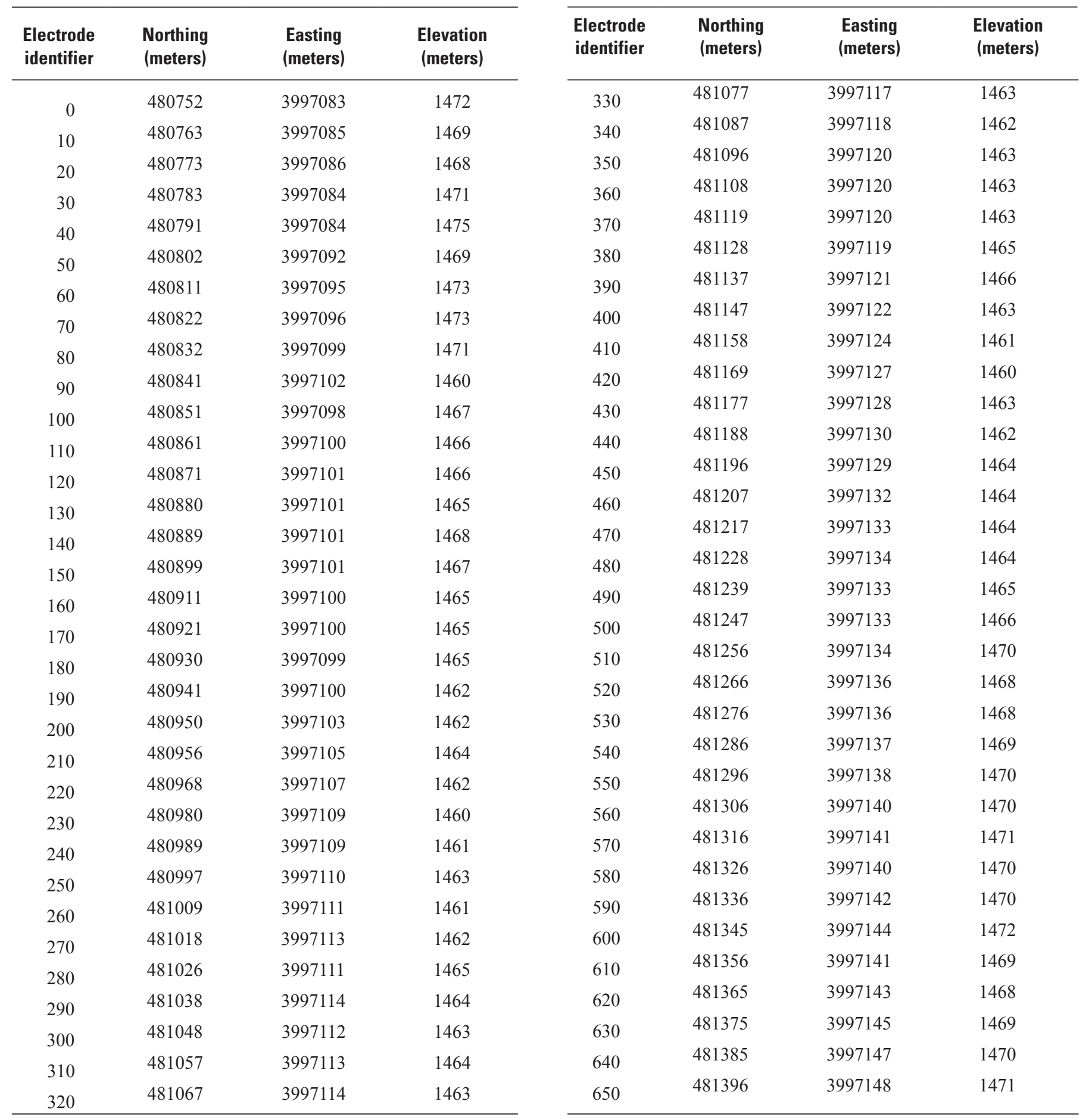


Table 1-4. Receiver Station Location of each CSAMT electrode for Line D.

[Coordinate system: Universal Transverse Mercator Zone 11, North American Datum of 1983; elevation is in meters above the North American Vertical Datum of 1988]

\begin{tabular}{|c|c|c|c|}
\hline $\begin{array}{l}\text { Electrode } \\
\text { identifier }\end{array}$ & $\begin{array}{l}\text { Northing } \\
\text { (meters) }\end{array}$ & $\begin{array}{c}\text { Easting } \\
\text { (meters) }\end{array}$ & $\begin{array}{c}\text { Elevation } \\
\text { (meters) }\end{array}$ \\
\hline 0 & 481236 & 3997547 & 1466 \\
\hline 20 & 481228 & 3997527 & 1466 \\
\hline 40 & 481222 & 3997509 & 1465 \\
\hline 60 & 481216 & 3997489 & 1466 \\
\hline 80 & 481209 & 3997471 & 1467 \\
\hline 100 & 481202 & 3997453 & 1468 \\
\hline 120 & 481195 & 3997433 & 1467 \\
\hline 140 & 481191 & 3997412 & 1466 \\
\hline 160 & 481181 & 3997396 & 1464 \\
\hline 180 & 481175 & 3997378 & 1465 \\
\hline 200 & 481168 & 3997358 & 1460 \\
\hline 220 & 481163 & 3997339 & 1463 \\
\hline 240 & 481154 & 3997321 & 1464 \\
\hline 260 & 481147 & 3997302 & 1461 \\
\hline 280 & 481139 & 3997281 & 1465 \\
\hline 300 & 481132 & 3997262 & 1468 \\
\hline 320 & 481127 & 3997244 & 1468 \\
\hline 340 & 481118 & 3997228 & 1465 \\
\hline 360 & 481112 & 3997207 & 1466 \\
\hline 380 & 481107 & 3997188 & 1465 \\
\hline 400 & 481099 & 3997168 & 1467 \\
\hline 420 & 481095 & 3997154 & 1461 \\
\hline 440 & 481088 & 3997135 & 1461 \\
\hline 460 & 481082 & 3997117 & 1467 \\
\hline 480 & 481075 & 3997098 & 1462 \\
\hline 500 & 481070 & 3997078 & 1462 \\
\hline 520 & 481063 & 3997058 & 1462 \\
\hline 540 & 481054 & 3997042 & 1462 \\
\hline 560 & 481046 & 3997024 & 1461 \\
\hline 580 & 481037 & 3997006 & 1460 \\
\hline 600 & 481028 & 3996988 & 1461 \\
\hline
\end{tabular}

Table 1-5. Receiver Station Location of each CSAMT electrode for Line $\mathrm{E}$.

[Coordinate system: Universal Transverse Mercator Zone 11, North American Datum of 1983; elevation is in meters above the North American Vertical Datum of 1988]

\begin{tabular}{|c|c|c|c|}
\hline $\begin{array}{l}\text { Electrode } \\
\text { identifier }\end{array}$ & $\begin{array}{l}\text { Northing } \\
\text { (meters) }\end{array}$ & $\begin{array}{l}\text { Easting } \\
\text { (meters) }\end{array}$ & $\begin{array}{c}\text { Elevation } \\
\text { (meters) }\end{array}$ \\
\hline 0 & 481406 & 3997559 & 1474 \\
\hline 20 & 481397 & 3997538 & 1473 \\
\hline 40 & 481390 & 3997520 & 1472 \\
\hline 60 & 481383 & 3997503 & 1472 \\
\hline 80 & 481377 & 3997485 & 1475 \\
\hline 100 & 481369 & 3997467 & 1474 \\
\hline 120 & 481364 & 3997449 & 1476 \\
\hline 140 & 481355 & 3997428 & 1474 \\
\hline 160 & 481349 & 3997409 & 1473 \\
\hline 180 & 481342 & 3997390 & 1472 \\
\hline 200 & 481336 & 3997372 & 1471 \\
\hline 220 & 481330 & 3997352 & 1470 \\
\hline 240 & 481325 & 3997333 & 1472 \\
\hline 260 & 481317 & 3997314 & 1472 \\
\hline 280 & 481310 & 3997295 & 1471 \\
\hline 300 & 481306 & 3997278 & 1469 \\
\hline 320 & 481298 & 3997258 & 1467 \\
\hline 340 & 481292 & 3997239 & 1469 \\
\hline 360 & 481285 & 3997221 & 1469 \\
\hline 380 & 481279 & 3997202 & 1467 \\
\hline 400 & 481271 & 3997184 & 1470 \\
\hline 420 & 481263 & 3997165 & 1468 \\
\hline 440 & 481255 & 3997146 & 1468 \\
\hline 460 & 481247 & 3997128 & 1467 \\
\hline 480 & 481239 & 3997108 & 1469 \\
\hline 500 & 481234 & 3997091 & 1469 \\
\hline 520 & 481225 & 3997072 & 1465 \\
\hline 540 & 481218 & 3997053 & 1462 \\
\hline 560 & 481210 & 3997036 & 1463 \\
\hline 580 & 481202 & 3997017 & 1462 \\
\hline 600 & 481192 & 3997000 & 1461 \\
\hline
\end{tabular}


Table 1-6. Receiver Station Location of each CSAMT electrode for Line F.

[Coordinate system: Universal Transverse Mercator Zone 11, North American Datum of 1983; elevation is in meters above th North American Vertical Datum of 1988]

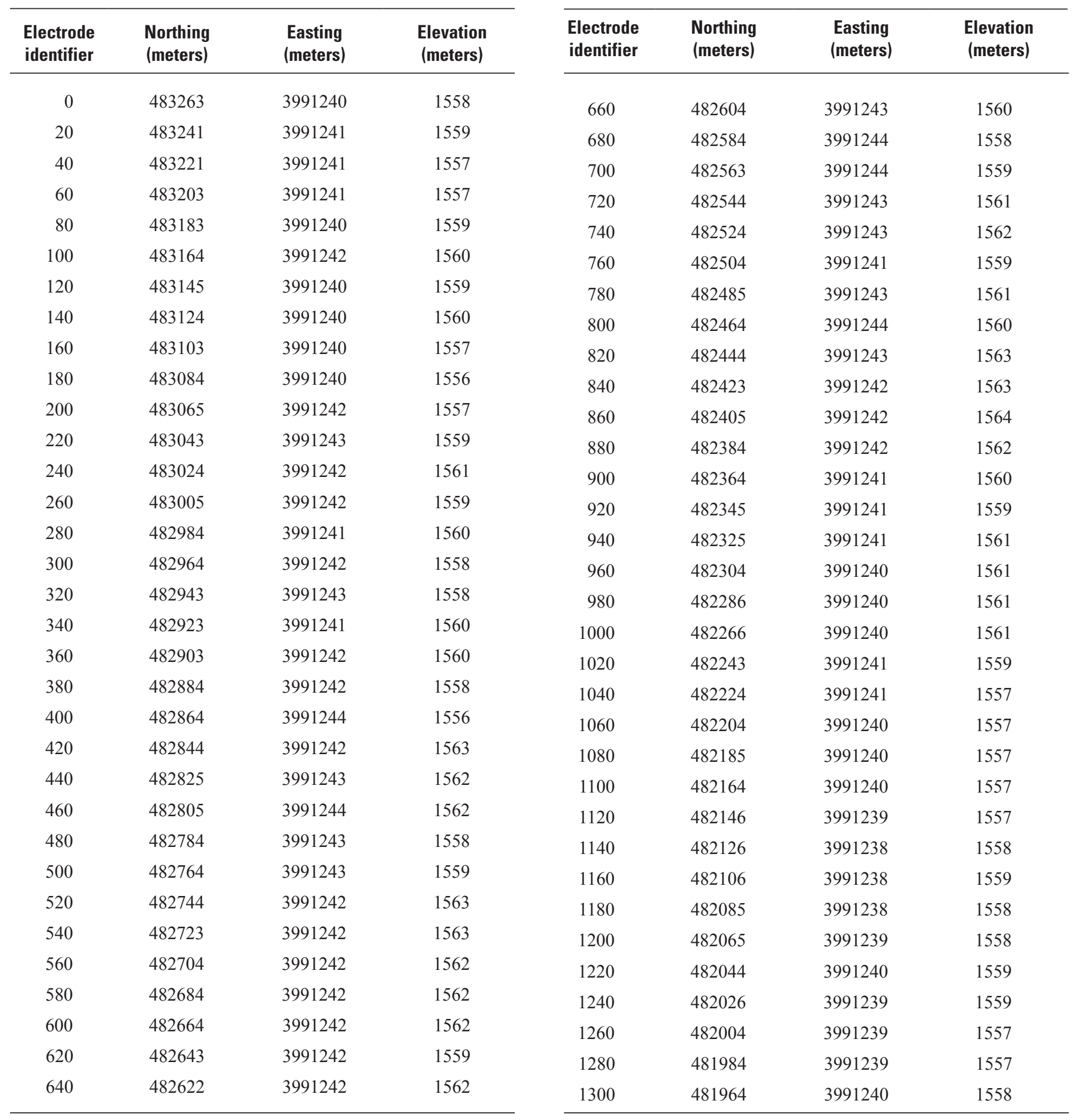


Produced in the Menlo Park Publishing Service Center, California Manuscript approved for publication, August 15, 2012

Text edited by Gail Sladek

Layout and Design by Jeanne S. DiLeo 
호

ํํำ.

음

E

ํํㄱ

몽

ㅎ.

先

홍

훅

뭉

ㄹ.

疋

序

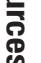

\%

के

产

음

궁

흘.

‥

잉

$\infty$

ㅁำ

ह่ำ

通

के 